\title{
Functional CD40 Ligand Is Expressed by T Cells in Rheumatoid Arthritis
}

\author{
Kelli P.A. MacDonald, ${ }^{\star}$ Yuichi Nishioka, ${ }^{\ddagger}$ Peter E. Lipsky, ${ }^{\ddagger}$ and Ranjeny Thomas ${ }^{\star}$ \\ *University of Queensland, Department of Medicine, Princess Alexandra Hospital, Brisbane, Queensland 4102, Australia; and ${ }^{*}$ University \\ of Texas Southwestern Medical Center, Dallas, Texas 75235-8884
}

\begin{abstract}
CD40 ligand (CD40-L), a member of the tumor necrosis family of transmembrane glycoproteins, is rapidly and transiently expressed on the surface of recently activated CD4+ $\mathrm{T}$ cells. Interactions between CD40-L and CD40 induce B cell immunoglobulin production as well as monocyte activation and dendritic cell differentiation. Since these features characterize rheumatoid arthritis (RA), the expression and function of CD40-L in RA was examined. Freshly isolated RA peripheral blood (PB) and synovial fluid (SF) T cells expressed CD40-L mRNA as well as low level cell surface CD40-L. An additional subset of CD4+ RA SF T cells upregulated cell surface CD40-L expression within $15 \mathrm{~min}$ of in vitro activation even in the presence of cycloheximide, but soluble CD40-L was not found in SF. CD40-L expressed by RA T cells was functional, since RA PB and SF T cells but not normal PB T cells stimulated CD40-L-dependent $B$ cell immunoglobulin production and dendritic cell IL-12 expression in the absence of prolonged in vitro $T$ cell activation. In view of the diverse proinflammatory effects of CD40-L, this molecule is likely to play a central role in the perpetuation of rheumatoid synovitis. Of importance, blockade of CD40-L may prove highly effective as a disease modifying therapy for RA. (J. Clin. Invest. 1997. 100:24042414.) Key words: autoimmunity $\bullet$ CD4 T cells $\bullet T$ cell activation $\cdot \mathrm{B}$ cells $\bullet$ inflammation
\end{abstract}

\section{Introduction}

Rheumatoid arthritis (RA) is an autoimmune disease in which an ongoing immune response to arthritogenic peptides results in a cascade of events leading ultimately to destruction of joint tissues. Thus, RA synovium is characterized by lymphocytic infiltration, T cell activation (1-5), B cell Ig production (6), monocyte cytokine production (7-9), and dendritic cell activation $(2,4-8,10,11)$. The lymphocytic infiltrate that accumulates within the chronically inflamed synovium contains a population of CD4+ T cells that is comprised almost exclusively of memory $\mathrm{T}$ cells expressing the leukocyte common antigen CD45RO $(12,13)$. Within this population of memory lympho-

Address correspondence to Dr. Ranjeny Thomas, University of Queensland, Department of Medicine, Princess Alexandra Hospital, Brisbane, Queensland 4102, Australia. Phone: 61-7-3240-5365; FAX: 61-7-3240-5946; E-mail: rthomas@gpo.pa.uq.edu.au

Received for publication 5 December 1996 and accepted in revised form 8 September 1997.

J. Clin. Invest.

(C) The American Society for Clinical Investigation, Inc. 0021-9738/97/11/2404/11 \$2.00

Volume 100, Number 9, November 1997, 2404-2414

http://www.jci.org cytes, there is an enrichment of $\mathrm{CD} 45 \mathrm{RB}^{\mathrm{dim}}$ memory $\mathrm{T}$ cells (14). The CD45RO+CD45RB ${ }^{\mathrm{dim}}$ phenotype reflects a differentiated effector $\mathrm{T}$ cell that has cycled through at least one activation event $(15,16)$. These RA synovial T cells exhibit an enhanced capacity to provide help for B cell Ig production and a reduced suppressor activity (14). However, despite evidence of $\mathrm{T}$ cell activation in RA, their role in the disease pathogenesis has been questioned $(17,18)$.

Many cytokines produced by activated T cells, such as IFN- $\gamma$, IL-2, and IL-4, are either absent or found at low levels within the rheumatoid synovium (19-21). Furthermore, treatments directed against $\mathrm{CD} 4+\mathrm{T}$ cells, such as thoracic duct drainage and cyclosporine and $\mathrm{mAb}$ therapies, have provided inconsistent benefit in chronic RA (22-25). Finally, therapeutic use of $\mathrm{mAb}$ directed against monocyte-derived proinflammatory cytokines such as TNF- $\alpha$ has proved highly effective in ameliorating the disease, even though it is not remission-inducing (26, 27 ). Taken together, these findings have led many to hypothesize that monocyte-derived cytokines are the principal factors driving the local inflammatory response $(28,29)$.

One of the most important signals for B cell Ig production is derived from interactions between CD40 ligand (CD40-L) ${ }^{1}$ and CD40. Activation of CD4+ T cells after antigen presentation results in the upregulation of expression of CD40-L. CD40-L is a $33-\mathrm{kD}$ glycoprotein that is rapidly and transiently expressed on the surface of recently activated CD4+ T cells (30). CD40-L, a member of the TNF family of proteins, exhibits homology with TNF- $\alpha$ (30). Both membrane-bound and soluble forms of CD40-L have been identified and demonstrated to be biologically active (31). Based on the similarity in primary structure between $\mathrm{CD} 40-\mathrm{L}$ and $\mathrm{TNF}-\alpha$, both the membrane-bound and soluble forms of CD40-L are predicted to exist as native trimers $(32,33)$.

CD40 is expressed by B cells, monocytes, and dendritic cells in their unactivated state $(34,35)$. Ligation of B cell CD40 induces proliferation, differentiation, Ig production, and isotype switching (34). CD40 ligation of monocytes increases cytokine production and tumoricidal activity $(36,37)$. Ligation of dendritic cell CD40 enhances their differentiation and activation, with increased expression of the costimulatory molecules CD80 and CD86, increased cytokine production, and inhibition of apoptosis $(35,38)$. In view of the high levels of $\mathrm{Ig}$, rheumatoid factor, monocyte-derived cytokines, and dendritic cell activation that characterize RA, the expression and function of CD40-L in RA was examined. The data demonstrate expression of low levels of membrane CD40-L, as well as preformed CD40-L mRNA and protein within a subset of freshly isolated RA peripheral blood (PB) and synovial fluid (SF) T cells, that is capable of inducing Ig production by normal $\mathrm{B}$ cells and

1. Abbreviations used in this paper: CD40-L, CD40 ligand; CLL, chronic lymphocytic leukemia; GAMIg, goat anti-mouse Ig; MNC, mononuclear cells; PB, peripheral blood; SF, synovial fluid; TBS, Tris-buffered saline. 
IL-12 expression by monocyte-derived dendritic cells. In view of the diverse proinflammatory effects of CD40-L, these data indicate that CD4+ T cell-expressed CD40-L is likely to play a central role in rheumatoid synovitis, and suggest that the CD40-CD40-L interaction may be an important therapeutic target in RA.

\section{Methods}

Patients. 21 patients who fulfilled the 1987 American College of Rheumatology criteria for RA (39) were studied. PB and SF were obtained from 5 and 12 of these patients, respectively, and synovial tissue was obtained from one patient while undergoing joint replacement surgery, and from three patients with recent onset, untreated RA by arthroscopic biopsy. Five of the patients were either on no medication or were taking low-dose prednisone $(<10 \mathrm{mg} / \mathrm{d})$. One patient was treated with intramuscular gold, nine with methotrexate, one with D-penicillamine, and three with sulfasalazine. Eight patients were treated with low-dose prednisone in combination with their disease-modifying drug.

$m A b s$. The following mAbs were used: anti-CD3 mAb 64.1 (14) and OKT3 (American Type Culture Collection, Rockville, MD); MT310, anti-CD4-PE (DAKO Corp., Carpinteria, CA); Leu M3, anti-CD14 (Becton Dickinson, San Jose, CA); Leu 11b, anti-CD16 (Becton Dickinson); Leu 12, anti-CD19 (Becton Dickinson); Leu 19, anti-CD56 (Becton Dickinson); L243, anti-HLA-DR (American Type Culture Collection); biotinylated C8.6, anti-human IL-12 p40 (PharMingen, San Diego, CA); biotinylated 24-31, anti-human CD40-L (Ancell Corp., Bayport, MN); TRAP1, anti-CD40-L (Immunotech, Marseille, France); 5C8, anti-CD40-L (a gift from Dr. Seth Lederman, Columbia University, NY); and M90, anti-CD40-L (a gift from Dr. Melanie Spriggs, Immunex, Seattle, WA). Secondary antibodies included biotinylated rabbit anti-mouse IgG (DAKO Corp.), FITC-conjugated goat anti-mouse Ig (GAMIg; Organon Teknika Corp., Durham, NC), avidin-FITC (DAKO Corp.), avidin-PE (DAKO Corp.), and avidin-Cyanin5 (Cy5; DAKO Corp.) were used where indicated. Control reagents included mouse IgG1 (DAKO Corp.), unconjugated P1.17 (American Type Culture Collection), or P1.17 that was biotinylated as described previously (40).

Cells and culture conditions. Mononuclear cells (MNC) were obtained from normal healthy donors or RA patients by centrifugation of SF or heparinized venous blood over Ficoll-diatrizoate gradients (Pharmacia Diagnostics AB, Uppsala, Sweden). The normal or RA PBMC or RA SF MNC suspensions were washed twice and incubated with neuraminidase-treated sheep red blood cells (N-SRBC). The rosetting and nonrosetting populations were then separated by Ficoll gradient centrifugation. After lysis of the red blood cells with $1 \mathrm{M}$ ammonium chloride, the $\mathrm{T}$ cell-enriched population was passed through a nylon wool column to remove macrophages. Greater than $85 \%$ of the recovered $\mathrm{T}$ cells expressed $\mathrm{CD} 3$ as determined by flow cytometry. In some instances, the $\mathrm{T}$ cells were purified further by magnetic immunodepletion, as described (11). Cells were incubated on ice for 30 min with $\mathrm{mAb}$ directed against CD14, CD16, CD19, and HLA-DR, washed, and then incubated with GAMIg-conjugated magnetic beads (Miltenyi Biotec Inc., Auburn, CA) for 30 min at $4^{\circ} \mathrm{C}$. The cells were passed over a column in a strong magnetic field (MACS; Miltenyi Biotec Inc.), and the negatively selected T cells were collected. By flow cytometry using anti-CD3 $\mathrm{mAb}$, purity was $>97 \%$.

For generation of monocyte-derived dendritic cells, the nonrosetting population was myeloid-enriched by magnetic immunodepletion using mAb directed against CD3, CD16, CD19, and CD56 (41). After purification, the cells were cultured at $1.3 \times 10^{6}$ cells $/ \mathrm{ml}$ in the presence of GM-CSF $(800 \mathrm{U} / \mathrm{ml})$ and IL-4 $(400 \mathrm{U} / \mathrm{ml})$ as described previously (42).

For B cell purification, PBMC were deleted of monocytes and natural killer (NK) cells by incubation with $5 \mathrm{mM}$ L-leucine methyl ester $\mathrm{HCl}$ (Sigma Chemical Co., St. Louis, MO) as described previously (43). The cells were washed twice and rosetted, as described above. The nonrosetting cells were treated with $0.1 \mathrm{mM}$ L-leucyl-leucine methyl ester $\mathrm{HCl}$ and rosetted again. The nonrosetting cells contained $>90 \%$ CD20+ B cells by flow cytometry (44). In some experiments indicated in the text, PBMC were purified from a patient with chronic lymphocytic leukemia (CLL). The CLL PBMC contained $>90 \%$ CD $19+$ B cells.

In some experiments, $\mathrm{B}$ and $\mathrm{T}$ cell mixtures were purified by panning of B cells. Cells were incubated with anti-CD19 mAb for 5 min at room temperature, and subjected twice to centrifugation for $1 \mathrm{~min}$ at $130 \mathrm{~g}$ onto GAMIg-coated plates (Antibodies Inc., Davis, CA). The nonadherent cells were collected, and the adherent B cells were discarded (45). Unless indicated otherwise, all cultures were carried out in RPMI 1640 (GIBCO BRL, Gaithersburg, MD) supplemented with penicillin G $(200 \mathrm{U} / \mathrm{ml}$; Commonwealth Serum Laboratories, Parkville, Victoria, Australia), gentamicin $(10 \mu \mathrm{g} / \mathrm{ml})$, L-glutamine $(0.3 \mathrm{mg} / \mathrm{ml}$; Trace Biosciences Pty. Ltd., Castle Hill, New South Wales, Australia), and 10\% FCS (Commonwealth Serum Laboratories).

Immunohistochemistry. 5- $\mu \mathrm{m}$ frozen sections were stained to reveal expression of CD40-L using an immunoalkaline phosphatase staining procedure. Briefly, sections were blocked for $20 \mathrm{~min}$ in $10 \%$ rabbit serum $/ 10 \%$ FCS in Tris-buffered saline (TBS), followed by a $60 \mathrm{~min}$ incubation in primary antibody (M90). Sections were then incubated in biotinylated rabbit anti-mouse Ig, which was visualized using the avidin-biotin method with SteptABComplex/AP followed by vector blue (Vector Laboratories, Inc., Burlingame, CA). Subsequently, the sections were counterstained with hematoxylin and imaged using confocal microscopy (Carl Zeiss Jena GmbH, Jena, Germany). All incubations were carried out at room temperature. Sections were washed with TBS between each incubation, and primary and secondary antisera were diluted in TBS at optimal titer. For control staining, irrelevant isotype-matched antibodies were applied.

$T$ cell activation. For reverse transcription (RT)-PCR analysis, normal PB T cells were activated by incubation in the presence of $10 \mathrm{ng} / \mathrm{ml}$ PMA (Sigma Chemical Co.) and $2.5 \mu \mathrm{g} / \mathrm{ml} \mathrm{PHA} \mathrm{(Glaxo}$ Wellcome Australia Ltd., North Sydney, New South Wales, Australia) for $24 \mathrm{~h}$. For CD40-L surface staining, purified T cells were activated by incubation in the presence of $10 \mathrm{ng} / \mathrm{ml}$ PMA and $5 \mu \mathrm{g} / \mathrm{ml}$ ionomycin (Sigma Chemical Co.) or in 96-well plates coated with 64.1 (14) for durations described in the text. For some experiments, after PMA and ionomycin activation, T cells were washed and fixed in $1 \%$ paraformaldehyde for $15 \mathrm{~min}$ at room temperature. Fixed cells were washed three times and incubated at $2 \times 10^{6}$ cells $/ \mathrm{ml}$ overnight at $37^{\circ} \mathrm{C}$ before using in subsequent cell culture experiments.

Cell staining and flow-cytometric analysis. Freshly purified cells were stained in the presence of $1 \%$ FCS for 30 min on ice. For twocolor staining, cells were incubated with either unconjugated $\mathrm{mAb}$, washed twice, then incubated with FITC-conjugated GAMIg and phycoerythrin (PE)-conjugated anti-CD4 $\mathrm{mAb}$, or incubated with biotinylated $\mathrm{mAb}$ followed by FITC-conjugated streptavidin and PEconjugated anti-CD4 mAb. Cells were washed and fixed in $1 \%$ paraformaldehyde and analyzed using a flow cytometer (Epics Elite ESP; Coulter Corp., Hialeah, FL). Where appropriate, differences were analyzed by the Mann Whitney $\mathrm{U}$ test.

RNA isolation and RT-PCR analysis. Total RNA was isolated using RNAzol (Biotecx Laboratories, Inc., Houston, TX) according to the manufacturer's instructions. First-strand cDNA was synthesized using oligo-(dT) $)_{20}$ (Pharmacia Diagnostics $\left.\mathrm{AB}\right)$ as a primer and AMV-RT (Promega Corp., Madison, WI) as described previously (14). Complementary DNA (equivalent to $10 \mathrm{ng}$ total RNA) was mixed with 50 pmol each of forward and reverse oligonucleotide primers, $200 \mu \mathrm{M}$ each of dGTP, dATP, dCTP, and dTTP (PerkinElmer Corp., Norwalk, CT) in $10 \mathrm{mM}$ Tris- $\mathrm{HCl}$ (pH 9.0), $1.5 \mathrm{mM}$ $\mathrm{MgCl}_{2}, 50 \mathrm{mM} \mathrm{KCl}$, and $0.1 \%$ Triton X-100 in a total volume of $50 \mu \mathrm{l}$. The reaction mix was heated at $95^{\circ} \mathrm{C}$ for 7 min before adding $2 \mathrm{U}$ Taq polymerase (Perkin-Elmer Corp.), followed by 35 cycles of $95^{\circ} \mathrm{C}$ $(1 \mathrm{~min}), 55^{\circ} \mathrm{C}(30 \mathrm{~s})$, and $74^{\circ} \mathrm{C}(1 \mathrm{~min} 30 \mathrm{~s})$, and a final extension step 
at $74^{\circ} \mathrm{C}$ for $7 \mathrm{~min}$. The $\mathrm{CD} 40-\mathrm{L}$ primer sequences were sense primer 5'-ATC TGC GGC CAC TGG ACT GC-3', and antisense primer $5^{\prime}$-TTC CAG GGT TAC CAA GTT GT-3' (46). The $\beta$-actin primers have been described previously (47). $10 \mu \mathrm{l}$ of the PCR product was analyzed by Southern blot for confirmation of specificity. After agarose gel electrophoresis, DNA was transferred to Hybond-N nylon membranes (Amersham International, Little Chalfont, UK) in $0.4 \mathrm{M}$ $\mathrm{NaOH}$ and probed using ${ }^{32} \mathrm{P}$-end-labeled internal oligonucleotides (CD40-L, 5' AGA TCC TTA TCC TTA CTG AA 3'; and $\beta$-actin, $5^{\prime}$ CTG AAC CCT AAG GCC AAC CGT 3'). After hybridization for $12 \mathrm{~h}$ at $55^{\circ} \mathrm{C}$, filters were washed in $0.1 \times$ SSC $(1 \times$ SSC: $150 \mathrm{mM}$ $\mathrm{NaCl}, 15 \mathrm{mM}$ Na citrate, $\mathrm{pH} 7.0), 1 \%$ SDS at room temperature and exposed to film for $2 \mathrm{~h}$.

Analysis of secreted Ig. B $\left(2.5 \times 10^{4}\right)$ and T cells $\left(5 \times 10^{4}\right)$ were cultured in the presence or absence of $\mathrm{mAb} 5 \mathrm{C} 8$ or an isotypematched control mAb (P1.17) in 96-well round-bottomed microtiter plates. After $10 \mathrm{~d}$ of incubation at $37^{\circ} \mathrm{C}$, supernatants were collected and frozen until analysis. Isotype-specific ELISAs were used for the quantitation of total $\operatorname{IgM}, \operatorname{IgG}$, and $\operatorname{IgA}$ in the culture supernatants as described previously (48). Briefly, flat-bottomed, 96-well plates (Dynatech Laboratories, Inc., Chantilly, CA) were coated with affinitypurified goat anti-human $\operatorname{IgM}, \operatorname{IgG}$, or $\operatorname{IgA}$ (Tago Inc., Burlingame, CA) diluted in borate-buffered saline by incubating overnight at $37^{\circ} \mathrm{C}$. After washing in Tween saline, the plates were incubated with serial dilutions of standard Ig preparations ( $\mathrm{IgA}$ and $\mathrm{IgG}$, Behring Diagnostics Inc., San Jose, CA; IgM, Tago Inc.) or culture supernatants for $2 \mathrm{~h}$ at $37^{\circ} \mathrm{C}$. The washed plates were then incubated with peroxidase-conjugated affinity-purified goat anti-human Ig antibodies (Tago Inc.). Plates were developed using $o$-phenylenediamine as the substrate, and the colored reaction product was measured with an ELISA reader (Biokinetics EL312; Bio-Tek Instruments, Inc., Winooski, VT). The amount of Ig in the supernatants was determined by comparison with a standard curve using the KinetiCalc program (Bio-Tek Instruments, Inc.). Duplicates for each culture condition were performed and differed by $<10 \%$. The sensitivities of the specific assays were $12 \mathrm{ng} / \mathrm{ml}$ for IgA and IgG, and $24 \mathrm{ng} / \mathrm{ml}$ for IgM.

Analysis of monocyte-derived dendritic cell IL-12 expression. Dendritic cells obtained from myeloid cells cultured for $5 \mathrm{~d}$ with GMCSF and IL-4 were cultured with or without 15-min PMA- and ionomycin-activated, fixed normal PB or RA SF T cells (dendritic cell/T cell ratio, 1:2) in the presence or absence of $5 \mu \mathrm{g} / \mathrm{ml}$ anti-CD $40-\mathrm{L}$ $\mathrm{mAb}$ 24.31. After a 14-h incubation, the cells were harvested, and cytospins were prepared. Cytospins were fixed in acetone for $2 \mathrm{~min}$ and allowed to air dry for $2 \mathrm{~h}$ before blocking in $10 \%$ porcine serum/ $10 \%$ FCS in TBS. The cytospins were then stained with the biotinylated anti-IL-12 p40 mAb C8.6, followed by streptavidin conjugated to horseradish peroxidase, which was localized using the chromagen diaminobenzidine tetrahydrochloride. Slides were imaged using confocal microscopy.

$\left[{ }^{35}\right.$ S]Methionine labeling. Nylon wool column-purified normal PB or RA SF T cells were washed and resuspended in prewarmed DME deficient in L-methionine and L-glutamine (ICN Biomedicals, Inc., Costa Mesa, CA) supplemented with $10 \%$ dialyzed FCS, penicillin $\mathrm{G}(200 \mathrm{U} / \mathrm{ml})$, gentamicin $(10 \mu \mathrm{g} / \mathrm{ml})$, and L-glutamine $(0.3 \mathrm{mg} /$ $\mathrm{ml})$. Cells were activated with PMA and ionomycin for $6 \mathrm{~h}$ at $37^{\circ} \mathrm{C}$ and $5 \% \mathrm{CO}_{2}$ in the presence of $0.4 \mathrm{mCi} / \mathrm{ml}{ }^{35} \mathrm{~S}$-TRANSLabel (ICN Biomedicals, Inc.). After activation, the cells were recovered by centrifugation and resuspended at $8 \times 10^{6}$ cells $/ \mathrm{ml}$ in NP-40 lysis buffer (150 mM NaCl, $1 \% \mathrm{NP}-40,50 \mathrm{mM}$ Tris, $\mathrm{pH}$ 8.0). After a 30-min incubation on ice, the nuclei were removed by centrifugation, and the cell lysates were subjected immediately to immunoprecipitation as described. The culture supernatants were filtered using a $0.22-\mu \mathrm{m}$ filter, and CD40-Fc immunoreactive protein was purified by immunoprecipitation.

CD40-Fc immunoprecipitation. Cell lysates, supernatant, sera, SF, or a trimeric human CD40-L/leucine-zipper fusion protein (huCD40LT, $1 \mu \mathrm{g} / \mathrm{ml}$; a gift from Dr. Melanie Spriggs) was precleared with protein A-Sepharose before immunoprecipitation with $1 \mu \mathrm{g}$ dimeric human CD40/IgG1 Fc fusion protein (CD40-Fc; a gift from Dr. Melanie Spriggs) and $30 \mu$ l protein A-Sepharose slurry. After an 18 -h incubation at $4^{\circ} \mathrm{C}$, the Sepharose beads were recovered by centrifugation, washed five times in NP-40 lysis buffer, and resuspended in $20 \mu \mathrm{l}$ of $2 \times$ SDS sample buffer (Bio-Rad Laboratories, Hercules, CA). For $\left[{ }^{35} \mathrm{~S}\right]$ methionine-labeled immunoprecipitated protein, the samples were separated by electrophoresis through a $12 \%$ polyacrylamide gel (49) and visualized by fluorography. Nonradiolabeled protein was separated through $12 \%$ polyacrylamide gels and transferred electrophoretically to nitrocellulose membranes (Amersham International) in transfer buffer containing $48 \mathrm{mM}$ Tris, $39 \mathrm{mM}$ glycine, and $20 \%$ methanol. After transfer, the membranes were blocked for $1 \mathrm{~h}$ at room temperature in $10 \%$ skim milk powder that had been pretreated with immobilized streptavidin (Boehringer Mannheim, Mannheim, Germany) to remove endogenous biotin. The membranes were then incubated in either biotinylated CD $40-\mathrm{L} \mathrm{mAb}(0.5 \mu \mathrm{g} / \mathrm{ml})$ or an equal concentration of an irrelevant $\mathrm{mAb}$, followed by streptavidin conjugated to horseradish peroxidase. Immunoreactive protein was visualized using chemiluminescence (ECL; Amersham International).

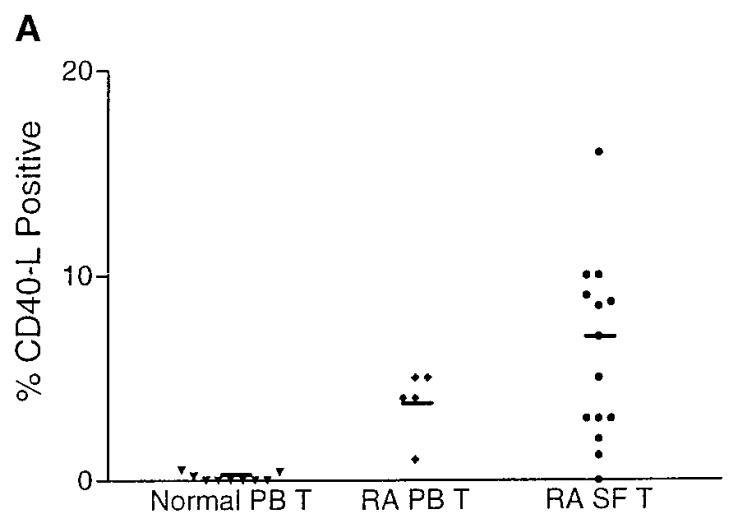

B

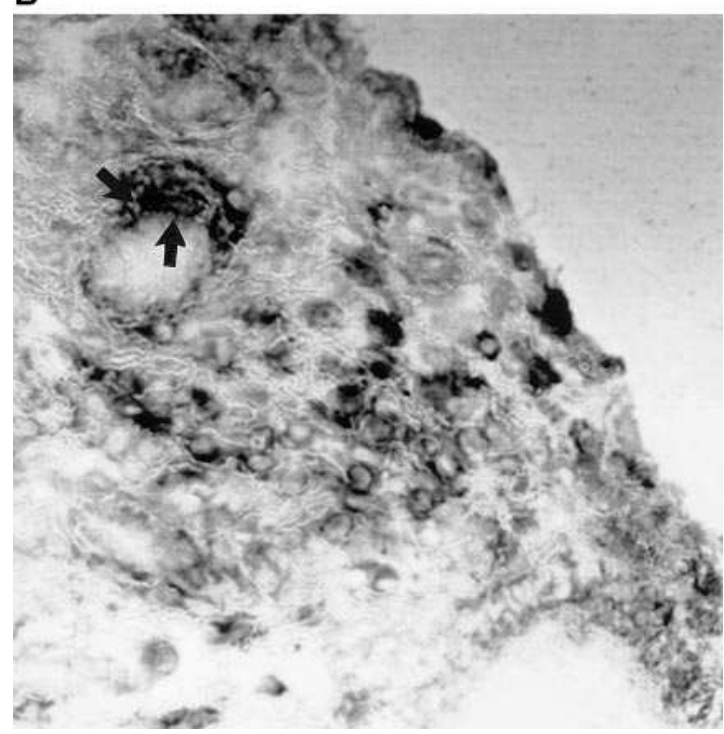

Figure 1. CD40-L expression by RA PB and SF T cells and in RA synovial tissue. $(A) \mathrm{T}$ cells were prepared from 9 normal PB, $5 \mathrm{RA}$ $\mathrm{PB}$, or $12 \mathrm{RA}$ SF samples by rosetting with neuraminidase-treated SRBC, and stained immediately with either biotinylated control $\mathrm{mAb}$ or biotinylated anti-CD40-L (mAb 24-31) followed by streptavidinFITC. (B) An immunoalkaline phosphatase staining method was used to reveal CD40-L expression in RA synovial tissue. Arrows, Vascular/perivascular staining; $\times 325$. 


\section{Results}

Freshly purified RA T cells express CD40-L $m R N A$ and elevated levels of cell surface CD40-L. Initial experiments characterized the expression of CD40-L in RA synovial tissue and by RA PB and SF T cells. Flow-cytometric analysis of cells stained with either $24-31,5 \mathrm{C} 8$, M90, or TRAP1 demonstrated low but statistically significant levels of CD40-L expression by freshly isolated RA PB and SF T cells as compared with normal PB T cells $(P<0.0001) .0 .1 \pm 0.1 \%$ (mean \pm SE) of normal PB T cells, $3.5 \pm 0.5 \%$ of RA PB T cells, and $6.0 \pm 1.2 \%$ of RA SF T cells expressed cell surface CD40-L (Fig. $1 A$ ). Immunohistochemical analysis of RA synovial tissue using an antiCD40-L mAb (M90) demonstrated CD40-L expression by infiltrating cells and associated with blood vessels (Fig. $1 B$ ).

After $6 \mathrm{~h}$ of activation with PMA and ionomycin, $\sim 17 \%$ of normal PB T cells and $\sim 27 \%$ of RA SF T cells expressed cell surface CD40-L (Fig. 2). Of note, the CD40-L ${ }^{+}$-activated RA SF T cells had diminished CD4 expression compared with either activated normal PB T cells or CD40-L-negative RA SF T cells.

Using human CD40-L and $\beta$-actin-specific oligonucleotides, RT-PCR demonstrated expression of CD40-L mRNA by activated but not freshly isolated normal PB T cells. In contrast, both freshly isolated RA PB and SF T cells expressed CD40-L mRNA (Fig. 3).

RA SF T cells contain preformed CD40-L. Preformed cytoplasmic CD40-L has been demonstrated previously in human tonsillar CD45RO+ T cells (50). Since CD40-L was expressed at low levels by $\mathrm{CD} 45 \mathrm{RO}+\mathrm{SF} \mathrm{T}$ cells, the next experiments examined whether the RA CD4+ T cells might also contain a preformed store of CD40-L. Purified normal PB or RA SF T cells were activated with immobilized anti-CD3, stained with $\mathrm{mAb}$ directed against CD4 and CD40-L, and analyzed using two-color flow cytometry. Within $15 \mathrm{~min}$ of activation, the percentage of SF T cells that expressed surface CD40-L was $\sim 20 \%$ greater than the percentage of freshly isolated $\mathrm{T}$ cells that expressed CD40-L (Fig. 4). No increase in CD40-L expression by normal $\mathrm{T}$ cells was observed during this time. To exclude the possibility of rapid de novo protein synthesis by the RA SF T cells, particularly in view of the expression of CD40-L mRNA, the same experiment was carried out in the presence of cycloheximide $(10 \mu \mathrm{g} / \mathrm{ml}$; Sigma Chemical Co. $)$. Whereas the initial upregulation of cell surface CD40-L expression occurred in either the presence or absence of cycloheximide, the addition of cycloheximide blocked further
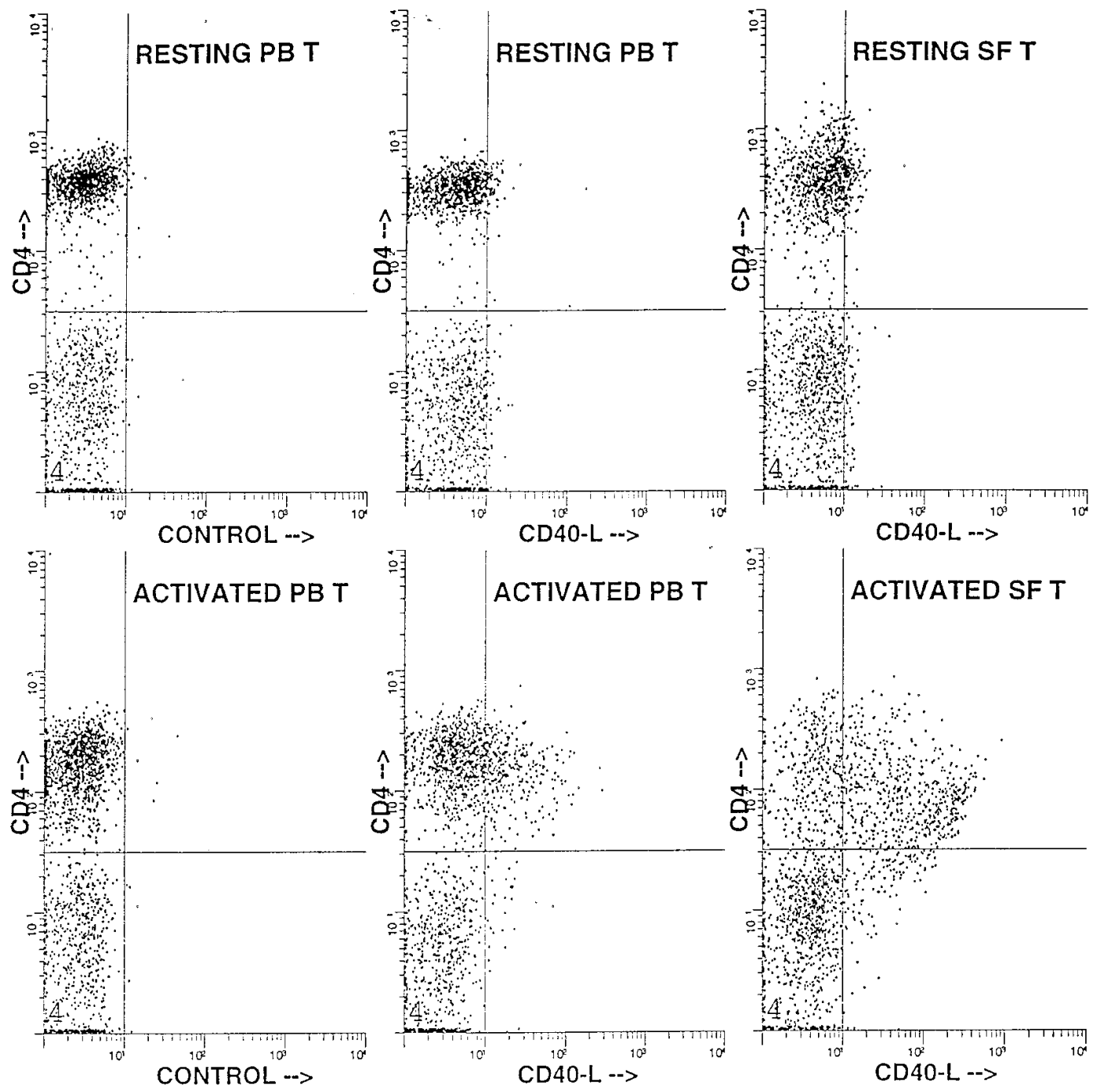

Figure 2. CD4 and CD40-L expression by normal PB and RA SF T cells. T cells were prepared from normal PB or RA SF by nylon wool passage of MNC. Purified $\mathrm{T}$ cells were stained immediately or after $6 \mathrm{~h}$ of activation with PMA and ionomycin, with either biotinylated control $\mathrm{mAb}$ or biotinylated antiCD40-L (mAb 24-31), followed by streptavidinFITC, and finally antiCD4-PE. 

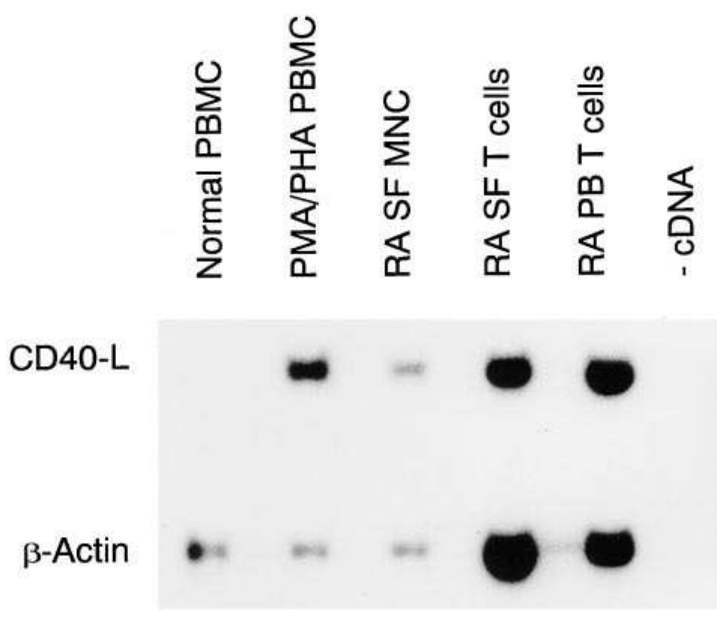

Figure 3. Characterization of CD40-L expression using RT-PCR cDNA derived from freshly purified or in vitro activated normal PBMC, or freshly purified RA PB or SF MNC or T cells was amplified with specific primers for either CD40-L or $\beta$-actin. Southern blots of the PCR products were probed with a radiolabeled internal oligonucleotide as described in Methods.
CD40-L upregulation after 1-3 h of activation (Fig. 5). Thus, a subpopulation of RA SF T cells contains preformed CD40-L that is expressed rapidly upon activation in vitro. In contrast, all surface CD40-L expressed by normal PB and upregulated by RA SF CD4+ T cells after initial expression and more prolonged activation requires de novo protein synthesis.

$R A P B$ and $S F T$ cells express functional $C D 40-L$. In vitro, Ig production by freshly isolated normal PB B cells can be induced in the presence of normal T cells only in the presence of an activation stimulus such as immobilized anti-CD3 or pokeweed mitogen, and CD40-CD40-L interactions are critical for B cell activation (51). Since the level of CD40-L on PB and SF T cells was low, it was important to determine whether freshly isolated RA $\mathrm{T}$ cells expressed functional levels of CD40-L. Normal PB B cells were incubated with either normal $\mathrm{PB}$, RA PB, or SF T cells in the presence of anti-CD40-L or control $\mathrm{mAb}$. RA SF and to a lesser extent PB T cells but not normal $\mathrm{T}$ cells induced CD40-L-dependent B cell Ig production (Fig. 6). The induced Ig consisted of IgM, IgG, and IgA. Although CD40-CD40-L interactions have been demonstrated to play a central role in Ig class switching (34), no conclusions regarding the nature of the $\mathrm{Ig}$ isotypes can be drawn
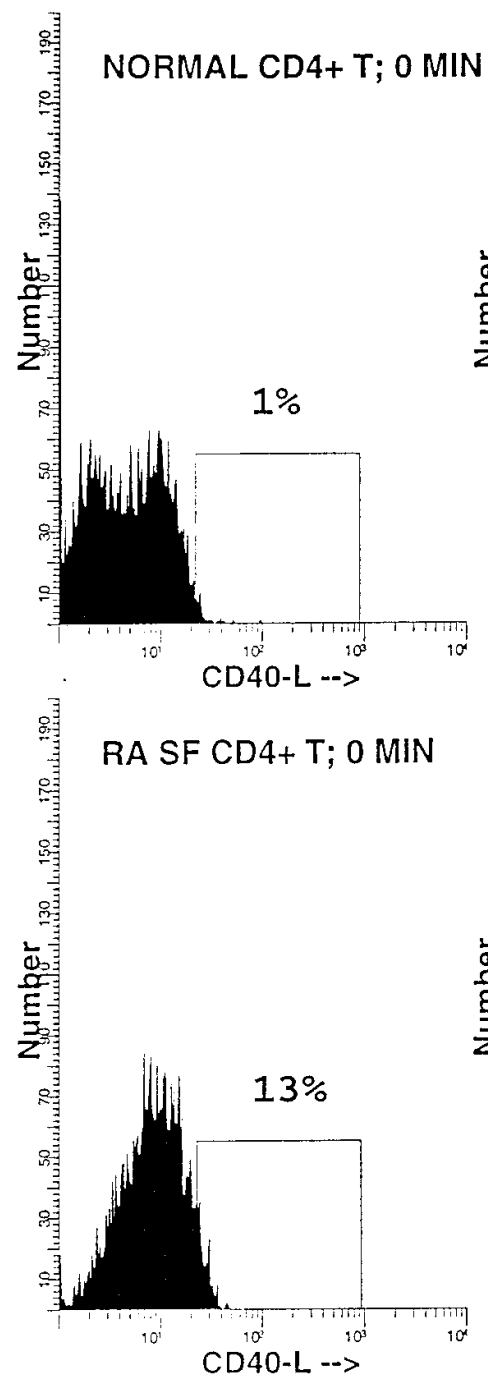

15 MIN
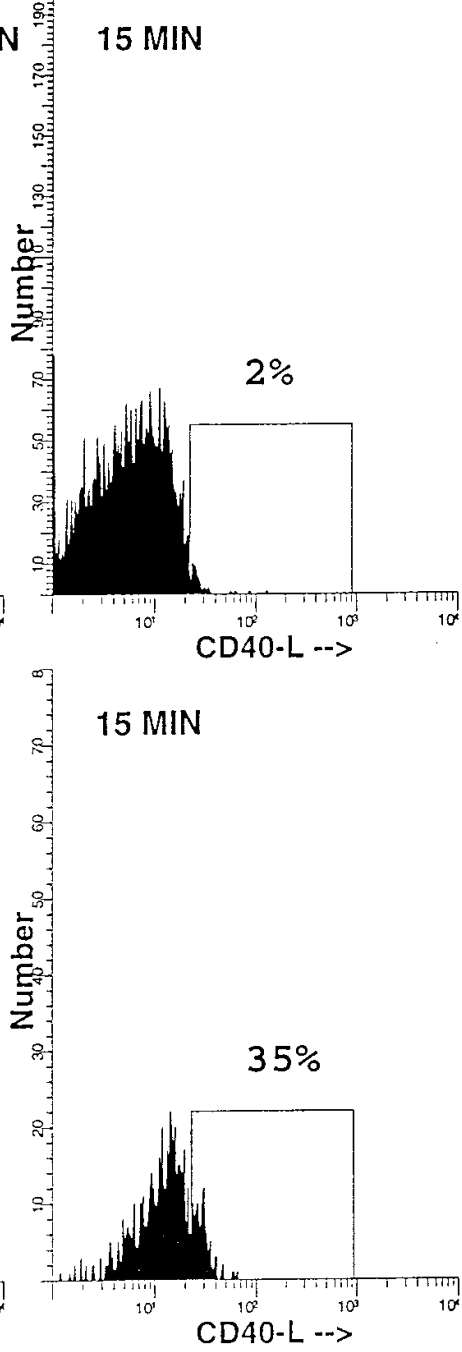
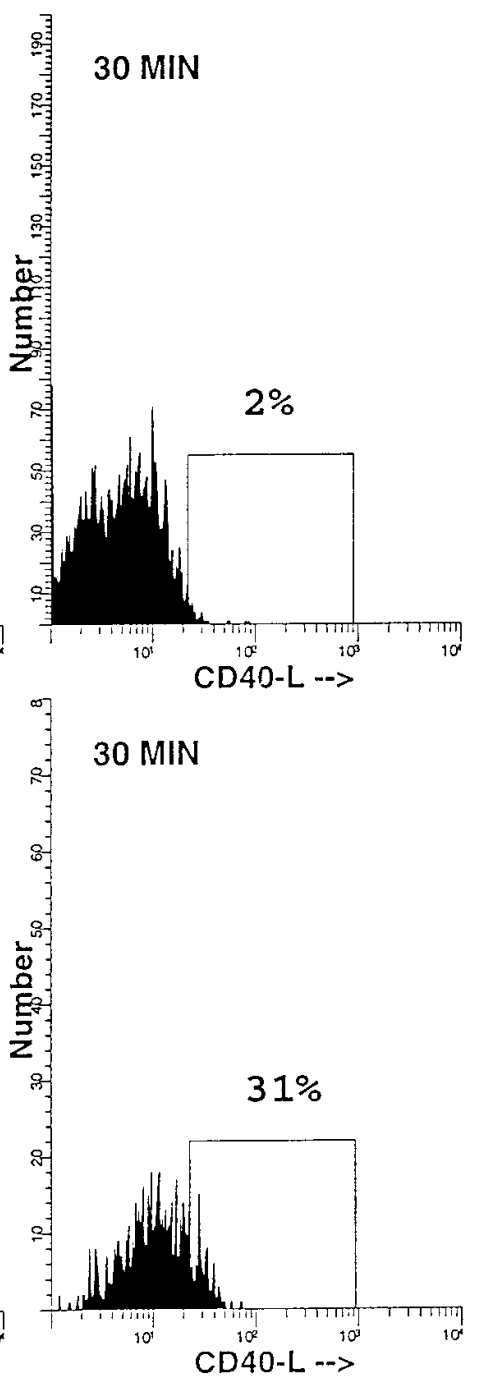

Figure 4. Induction of surface CD40-L expression by normal or RA SF CD4+ T cells after activation. Normal $\mathrm{PB}$ or RA SF T cells were prepared by passage of MNC over nylon wool, and activated in the presence of immobilized anti-CD3 mAb. Samples were collected at 15-min intervals and stained as described for Fig. 2. CD4+ cells were gated, and CD40-L expression by the $\mathrm{CD} 4+$ cells was analyzed. Data are representative of three separate experiments. 

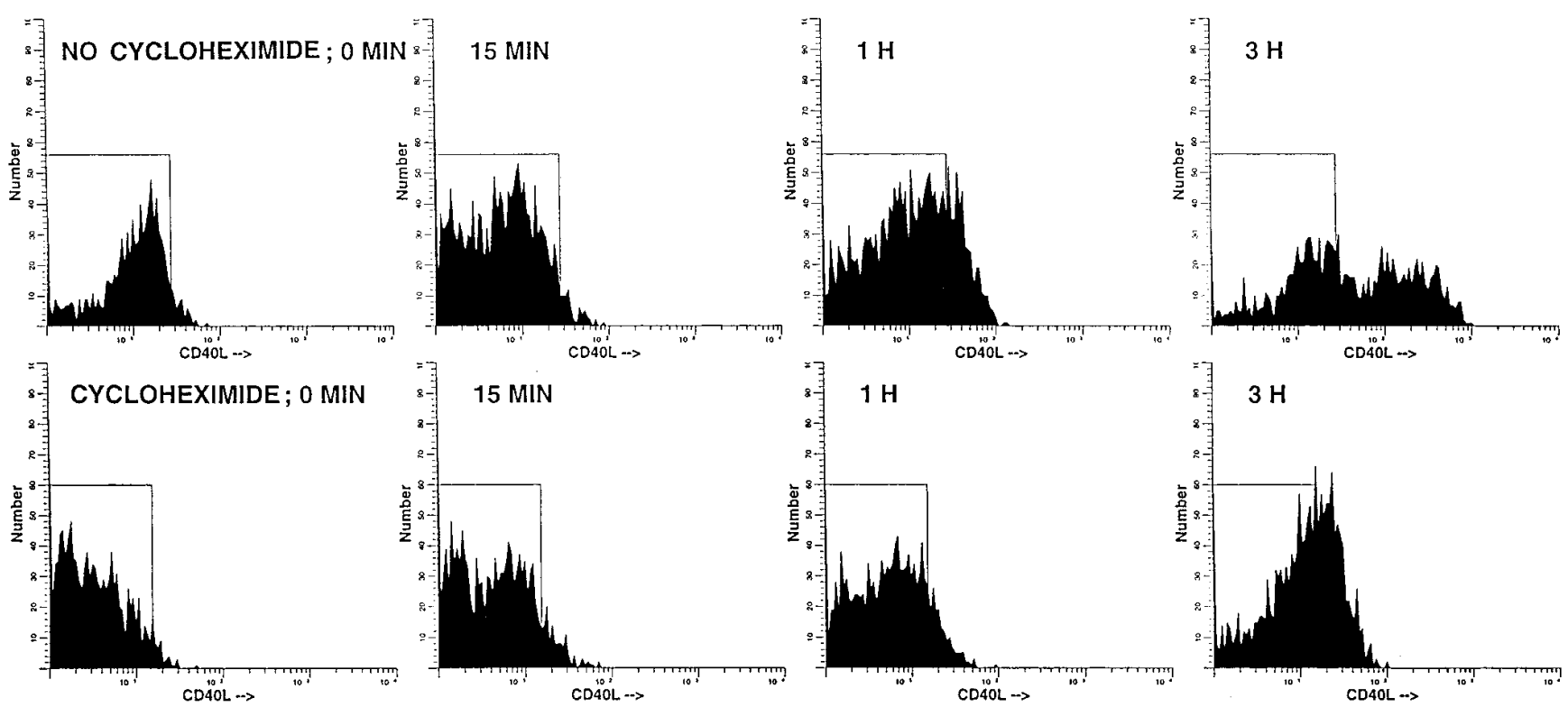

Figure 5. Cycloheximide does not block rapid CD40-L expression by RA SF T cells. RA SF T cells were incubated with or without cycloheximide for $2 \mathrm{~h}$, washed, and then activated with PMA and ionomycin, with or without cycloheximide, for various periods of time. CD40-L expression was analyzed as described for Fig. 2.

in this assay, as circulating memory and naive, as opposed to purified naive, B cells were used. As CD40-L stimulates all subsets of B cells, production of IgM and IgG is normally facilitated to a comparable extent, and of $\operatorname{IgA}$ to a lesser extent (51). Over a number of experiments, the percent inhibition of each isotype by anti-CD40-L ranged from 60 to $100 \%$. As can be seen, RA PB T cells stimulate very little, if any, CD40-Ldependent Ig production in accordance with the lower expression of CD40-L on the cell surface. Therefore, the data demonstrate that RA SF T cells express sufficient CD40-L to induce $\mathrm{B}$ cell $\mathrm{Ig}$ production in the absence of any in vitro activation stimulus.

Dendritic cell IL-12 production has been demonstrated recently to be upregulated greatly after ligation of CD40 by CD40-L (52). To confirm that CD40-L expressed by RA T cells was functional, IL-12 expression by monocyte-derived dendritic cells was examined in response to either normal PB or RA SF T cells in the presence or absence of anti-CD40-L mAbPreformedstoresolCD40-Lweremobilizedbyal 5-min

in vitro activation, and $\mathrm{T}$ cells were fixed before their addition to dendritic cells, to prevent further activation. The data demonstrate that RA SF but not normal T cells induced dendritic cell IL-12 expression in a CD40-L-dependent manner (Fig. 7).

Activated $T$ cells upregulate CD40-L expression after downmodulation by $B$ cells. It has been demonstrated previously that $\mathrm{T}$ cell surface CD40-L expression can be downmodulated, via receptor-mediated endocytosis, through interactions with B cell CD40 (53). The next experiments examined whether reactivation of $\mathrm{T}$ cells in which $\mathrm{CD} 40-\mathrm{L}$ had been downmodulated could lead to a similar rapid reexpression of CD40-L as that observed upon activation of RA SF T cells. For these experiments, purified normal PB T cells were activated for $3 \mathrm{~h}$ with PMA and ionomycin. After activation, downmodulation of $\mathrm{T}$ cell surface CD40-L was induced by a 2-h in- cubation with CLL PBMC at a T cell/B cell ratio of 1:5. The $\mathrm{B}$ cells were then removed by panning, and the T cells were restimulated with PMA and ionomycin. Cell surface CD40-L expression was analyzed using TRAP1 (Fig. 8). CD40-L was expressed by activated $\mathrm{T}$ cells, but downmodulated after incubation with B cells. Reactivation resulted in T cell CD40-L expression within 15 min. As demonstrated in Fig. 6, a 15-min activation of $\mathrm{T}$ cells in the absence of a 3 -h preactivation period did not induce CD40-L expression or background autofluorescence. These in vitro data suggest that B cell-induced endocytosis of CD40-L may contribute to the intracellular stores of preformed CD40-L that are available for reexpression upon subsequent activation.

Production of soluble CD40-L by RA SF T cells. Normal $\mathrm{PB} T$ cells have been shown previously to secrete a soluble form of CD40-L after in vitro activation (54). Since RA SF T cells are activated in vivo but produce lower levels of IL-2, IL-4, and IFN- $\gamma$ than activated normal PB T cells, the next experiments compared the levels of immunoprecipitated sCD40-L produced by $\left.{ }^{35} \mathrm{~S}\right]$ methionine-labeled normal PB and RA SF T cells activated for $6 \mathrm{~h}$ in the presence of PMA and ionomycin. Using CD40-Fc, a 33-kD protein corresponding to the fulllength membrane CD40-L and an $18-\mathrm{kD}$ protein corresponding to the soluble form of CD40-L (54) were each precipitated in equivalent amounts from normal PB and RA SF T cell lysates (Fig. 9 A). Supernatant from normal PB and RA SF T cell cultures contained a predominant $26-\mathrm{kD}$ protein and a small amount of an $18-\mathrm{kD}$ protein. Each was present at equivalent levels in RA SF and normal PB T cell supernatants.

The $26-\mathrm{kD}$ protein is likely to represent a cleavage product of membrane CD40-L, and the $18-\mathrm{kD}$ species, the secreted sCD40-L (54). Despite in vitro evidence of this secreted protein, there is as yet no evidence that it is produced in vivo. Since both of these proteins were found in SF T cell superna- 


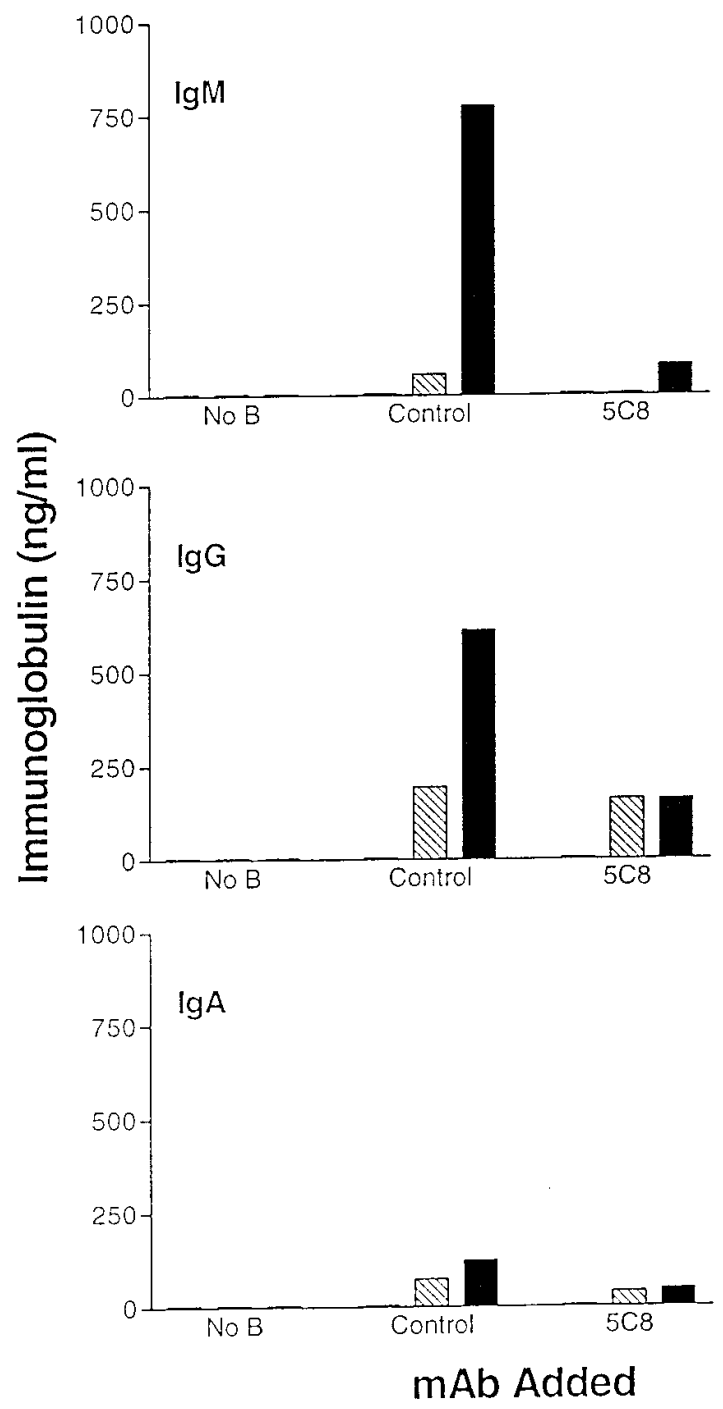

Figure 6. RA PB and SF T cells induce B cell Ig production. $5 \times 10^{6}$ normal PB (dotted bar), RA PB (striped bar), or SF (solid bar) T cells were incubated with $2.5 \times 10^{4}$ normal B cells for $10 \mathrm{~d}$ in the presence of the blocking anti-CD40-L mAb, 5C8, or control mAb. Supernatants were analyzed for IgM, IgG, or IgA by isotype-specific ELISA. Data are representative of three separate experiments.

tants, sCD40-L was sought in normal and RA serum and RA SF. Protein was immunoprecipitated using CD40-Fc and analyzed by immunoblotting, using a biotinylated anti-CD40-L $\mathrm{mAb}$. No immunoreactive protein was detected in any of the sera (data not shown) or SF samples, whereas huCD40LT was immunoprecipitated and detected readily (Fig. $9 B$ ).

\section{Discussion}

Strong evidence exists for the role of CD4+ T cells in B cell Ig production in the rheumatoid synovium. Ig levels are elevated in RA synovium, and disease severity is correlated with rheumatoid factor seropositivity $(6,55,56)$. The expression of CD45RO and enrichment in CD45RB ${ }^{\mathrm{dim}}$ cells $(14,57,58)$ suggests further that rheumatoid synovial CD4+ $\mathrm{T}$ cells have been stimulated previously, possibly multiple times $(15,16)$.
The ability of RA SF and synovial tissue CD4+ T cells to provide $B$ cell help in the presence of in vitro activation has been demonstrated (14). However, the constitutive capacity of freshly isolated RA T cells to provide B cell help allows a more appropriate estimation of their in vivo function. In this study, CD4+ RA PB and SF T cells were found to express CD40-L mRNA and to manifest low level expression of membrane CD40-L as well as preformed stores of CD40-L, and could induce $B$ cell activation and dendritic cell IL-12 expression in a CD40-L-dependent manner. CD40-L expression by activated $\mathrm{T}$ cells appears to be tightly regulated, in that cell surface expression can be detected within 1-2 $\mathrm{h}$ of activation, is maximal at $3-9 \mathrm{~h}$, and is undetectable within $24-72 \mathrm{~h}(50,59)$. Therefore, these data suggest that at least a subpopulation of CD4+ RA T cells has been activated recently to express CD40-L mRNA and protein in vivo, and that this CD40-L is likely to be of functional significance.

Since only low levels of CD40-L expression by either RA $\mathrm{PB}$, RA SF, or RA synovial tissue T cells were observed, it is possible that the CD40 binding epitope recognized by these anti-CD40-L mAbs might have been masked by soluble CD40 that had bound in vivo (60). Attempts were made to clarify this issue by staining freshly purified normal and RA T cells with the TRAP1 anti-CD40-L mAb that is reported to bind CD40-L at a site distinct from the CD40 binding epitope (61). However, in preliminary experiments, commercially obtained TRAP1 mAb blocked CD40-Fc binding to activated T cells and CD40-L-induced B cell proliferation (data not shown). Since this $\mathrm{mAb}$ appeared to recognize a CD40-L epitope near the binding site, and other mAbs to portions of CD40-L not involved in CD40 binding are not available, the question of masking of CD40-L by soluble CD40 in vivo could not be addressed definitively. Therefore, it remains possible that the levels of surface CD40-L might be underestimated because of masking of the CD40-binding site and the epitope recognized by anti-CD40-L mAb by soluble CD40. Regardless, both in vitro and in vivo evidence suggest that even low level CD40-L expression by freshly purified RA PB and SF CD4+ T cells is physiologically relevant. First, as shown here, CD40-L-dependent Ig production by normal B cells could be induced in the absence of in vitro activation. It is quite possible that the higher levels of Ig production stimulated by RA SF as compared with RA PB T cells relate to a higher expression of other adhesion and costimulatory molecules by the SF T cells (4) as well as the higher expression of CD40-L. In particular, at low levels of CD40-L expression, signaling through adhesion molecules may provide important additive effects (51). Furthermore, RA SF but not normal PB T cells strongly upregulated dendritic cell intracellular IL-12 production in a CD40dependent manner. Second, an in vitro model demonstrated recently induction of $\mathrm{CD} 40-\mathrm{L}$ expression by $<12 \%$ of CD45RA $+\mathrm{T}$ cells in the presence of immobilized anti-CD3. However, in the presence of IL-4, these T cells could induce CD40-L-dependent IgE synthesis (62). Therefore, low levels of CD40-L expression can be physiologically relevant. Third, maternal carriers of X-linked hyper-IgM syndrome have a greatly reduced number of PBMC with the capacity to express functional CD40-L, yet these individuals exhibit a functionally normal immune system (63). Finally, after in vitro activation, normal PB B cells express CD40-L protein and mRNA, although at significantly lower levels than are found on activated normal peripheral $\mathrm{T}$ cells. This small amount of B cell surface 


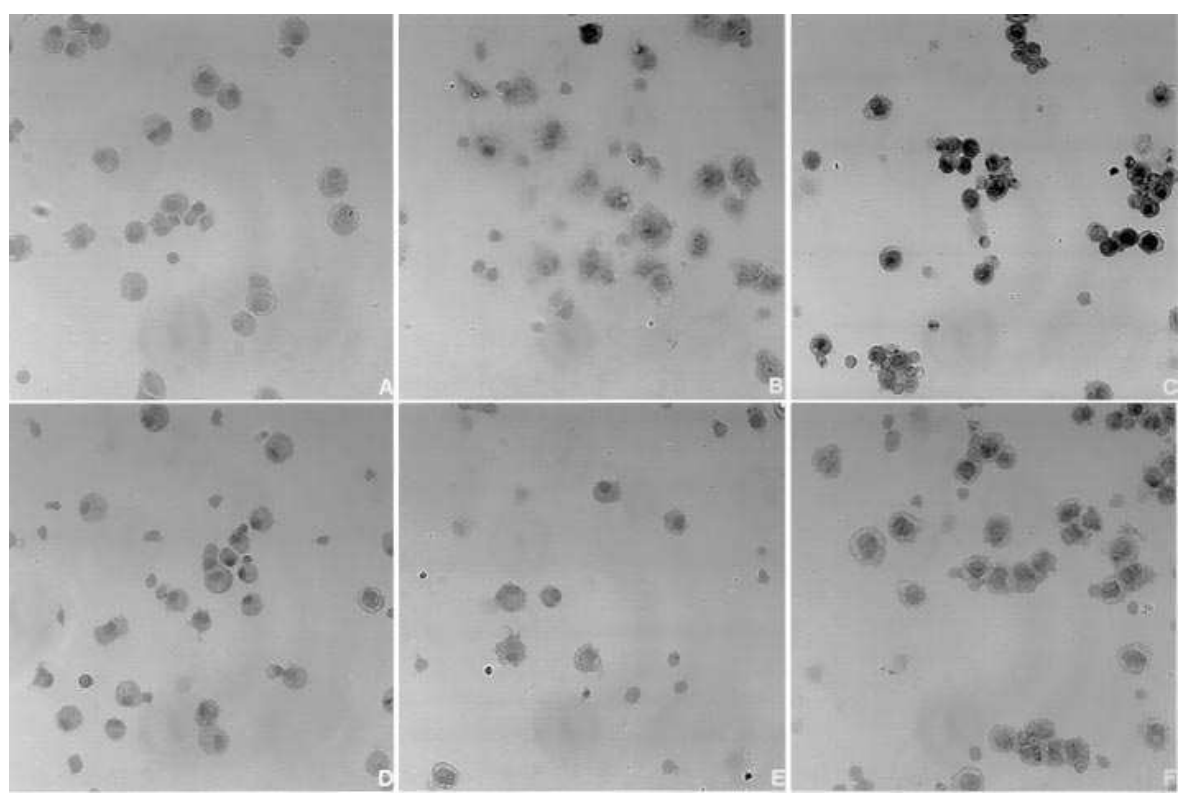

Figure 7. Dendritic cells upregulate IL-12 expression in response to RA SF T cell CD40-L. Monocyte-derived dendritic cells were cultured on their own $(A$ and $D)$ or stimulated with 15 -min activated, fixed normal PB ( $B$ and $E$ ) or RA SF ( $C$ and $F$ ) $\mathrm{T}$ cells in the presence $(D-F)$ or absence $(A-C)$ of an anti-CD40-L mAb. Staining with a negative control $\mathrm{mAb}$ was identical to $A$. After $14 \mathrm{~h}$ of incubation, the cells were harvested, cytospins were prepared, and intracellular IL-12 was detected using an anti-IL-12 p40 mAb.
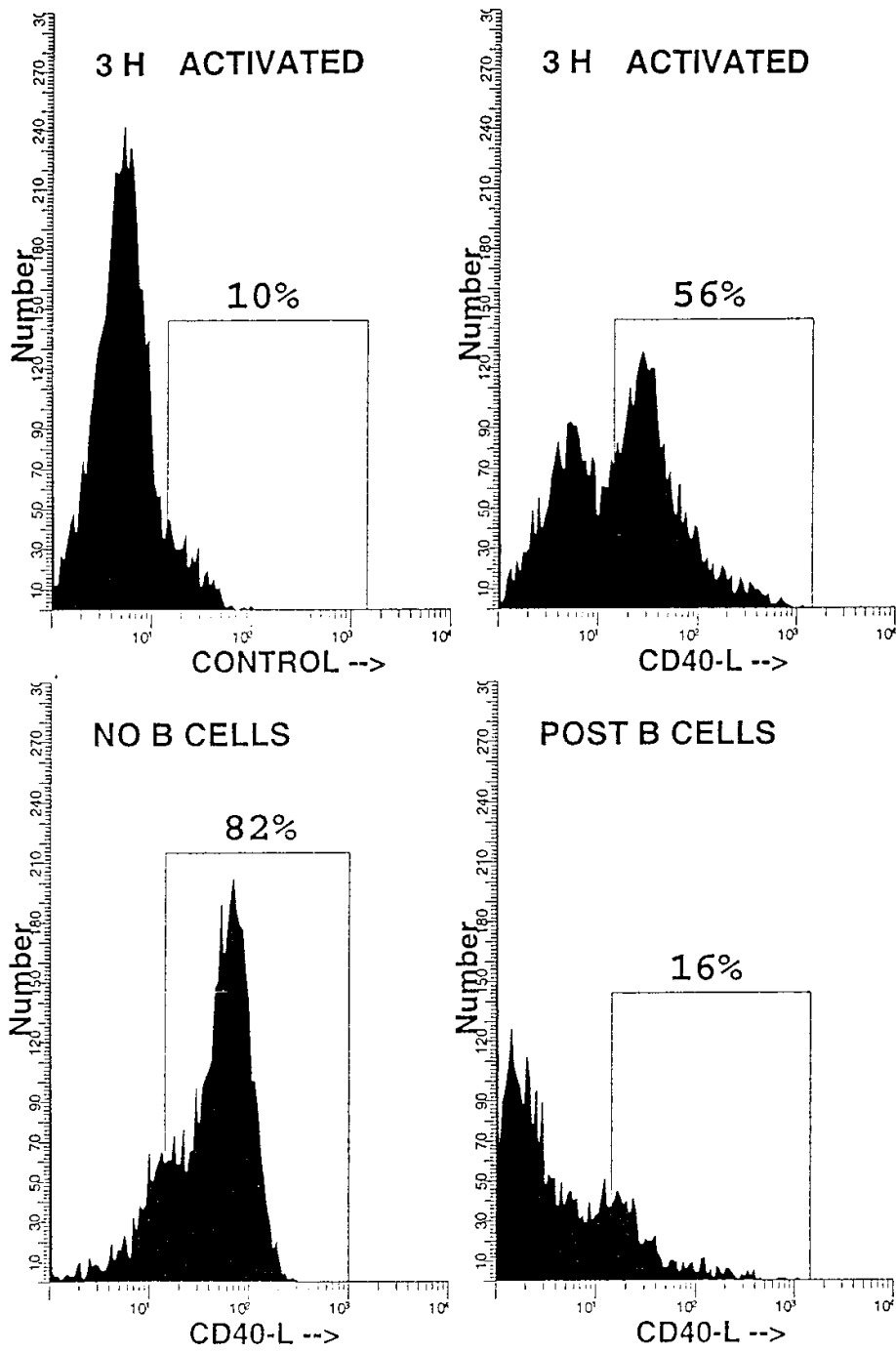

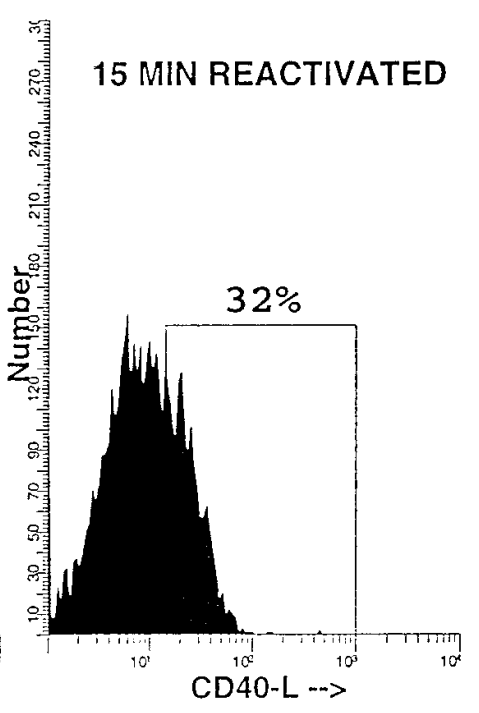

Figure 8. Activated $\mathrm{T}$ cells upregulate CD40-L expression after downmodulation by B cells. Normal PB T cells were incubated with PMA and ionomycin for $3 \mathrm{~h}$, washed, and incubated with or without CLL PBMC for $2 \mathrm{~h}$. $B$ cells were then removed by panning, and the $T$ cells were reincubated for 15 min with PMA and ionomycin. CD40-L expression was detected by staining with TRAP1 followed by biotinylated rabbit antimouse IgG and then streptavidin-FITC. 


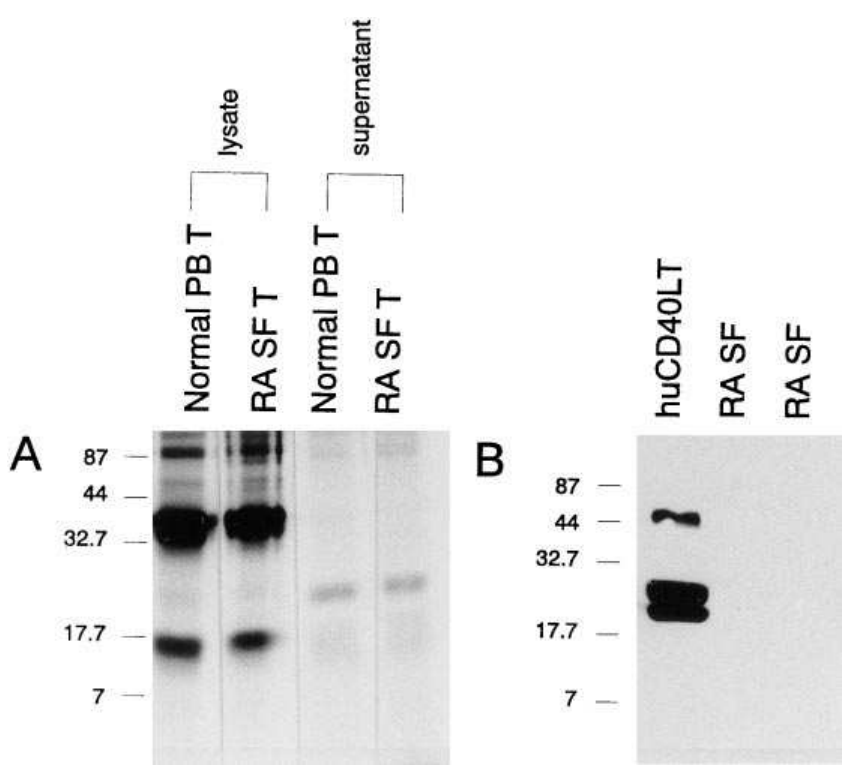

Figure 9. Production of soluble CD40-L by RA SF T cells. $(A)$ Normal PB or RA SF T cells were incubated for $6 \mathrm{~h}$ in medium deficient in L-methionine in the presence of PMA and ionomycin and ${ }^{35} \mathrm{~S}$ TRANSlabel. CD40-L immunoreactive protein was purified by immunoprecipitation with CD40-Fc. Immunoprecipitated proteins were separated by electrophoresis and analyzed by fluorography. (B) RA $\mathrm{SF}$ or huCD40LT was precleared with protein A-Sepharose, then immunoprecipitated with CD40-Fc and protein A-Sepharose. Immunoprecipitated proteins were separated by electrophoresis, analyzed by immunoblotting with biotinylated anti-CD40-L (mAb 24-31), and visualized by chemiluminescence.

CD40-L is sufficient for mediation of B cell homotypic aggregation and for the induction of Ig secretion by resting PB B cells (60). Together, these data indicate a requirement for only a small number of CD40-L-expressing T cells and a low density of CD40-L expression for functional activity in vivo.

These data provide evidence for stores of intracellular CD40-L within RA SF T cells. Previously, preformed CD40-L has been demonstrated in human tonsillar CD45RO+ T cells (50). While much of the CD40-L expression in RA ST was located on cell membranes, at least some staining appears more diffuse and intracellular. CD40-L expression was noted consistently on and around blood vessels. This is of interest, in view of the recent demonstration of CD40-L expression by endothelial cells (64). Although its functional significance is as yet unknown, CD40-L expressed by rheumatoid synovial endothelial cells could play a role in the activation of emigrating B cells and myeloid cells.

CD40 expressed by B cells but not monocytes is capable of downregulating CD40-L $(53,65)$. In this study, CD40-L was downregulated by incubation with $\mathrm{B}$ cells but was unaffected by incubation with monocytes or dendritic cells (data not shown). Therefore, one mechanism of regulation of $\mathrm{T}$ cell CD40-L expression might be via B cell membrane or soluble CD40-induced internalization by receptor-mediated endocytosis, followed by lysosomal degradation $(53,65)$. The inability of monocytes or dendritic cells to downregulate CD40-L expression may relate to their ability to costimulate $\mathrm{T}$ cells simultaneously through molecules such as CD86 (66). The ability of T cells to reexpress cell surface CD40-L suggests that if sequen- tial T cell activation events occurred in RA synovium, intracellular CD40-L within CD4+ memory $\mathrm{T}$ cells might provide a store of rapidly inducible cell surface CD40-L.

The small percentage of freshly isolated RA PB and SF T cells that expresses membrane CD40-L is likely to reflect the tight regulation of CD40-L expression in vivo. As demonstrated here and elsewhere, this might occur through interaction with B cells, or via cleavage from the cell surface (53). It has been reported previously that in vitro activated normal PB $\mathrm{T}$ cells express both a $33-\mathrm{kD}$ surface and an $18-\mathrm{kD}$ soluble form of CD40-L, and that both forms are biologically active (31). Whereas an $18-\mathrm{kD}$ form of CD40-L could be immunoprecipitated from the cell lysates of in vitro activated normal $\mathrm{PB}$ and RA SF T cells, in this study, this form of CD40-L was detected only at very low levels in the culture supernatant of either cell type. Surprisingly, a more predominant $26-\mathrm{kD}$ form of CD40-L was detected within both the activated normal and SF $\mathrm{T}$ cell supernatants. This finding is in contrast to a previous study in which the sole form of soluble CD40-L produced by in vitro activated $\mathrm{PB}$ T cells was reported to correspond to a molecular mass of $18 \mathrm{kD}$ (31). The $26-\mathrm{kD}$ protein may reflect degradation of surface CD40-L during cell activation, and it is possible that this discrepancy reflects different methods of cell activation and/or the use of different reagents for immunoprecipitation. Although soluble CD40-L was detected in RA SF T cell supernatants, none was present in RA SF. It is probable that any soluble CD40-L produced in SF is sequestered immediately by soluble or cellular CD40 or is degraded. Thus, the biological significance of sCD40-L is still unclear. Nevertheless, sCD40-L produced locally by activated $\mathrm{T}$ cells may well be capable of stimulating B cells in close proximity within the microenvironment, although a more distant endocrine effect seems unlikely.

After in vitro activation, the subset of SF T cells that expressed CD40-L also had diminished CD4 expression. CD4 expression is downregulated after activation, and this decrease in expression becomes more pronounced during longer periods of activation (67). Previously, the finding that RA SF T cells secrete only small amounts of IL-2, exhibit decreased IL-2receptor expression, and proliferate poorly in response to stimulation has led to the suggestion that RA SF T cells are anergic (68). However, these studies provide evidence against this. Whereas anergic $\mathrm{T}$ cells have a reduced capacity for CD40-L mRNA and protein expression (69), SF T cells were fully capable of CD40-L expression in vivo, and upregulated CD40-L expression upon activation to an even greater extent in vitro than normal PB T cells. Therefore, these data, together with the phenotype $\mathrm{CD} 4{ }^{\mathrm{dim}} \mathrm{CD}_{45 \mathrm{RB}^{\mathrm{dim}}} \mathrm{CD} 27-$, are consistent with the idea that RA synovial $\mathrm{T}$ cells are highly differentiated memory $\mathrm{T}$ cells that have undergone at least one and possibly multiple activation cycles (70). Reduced IL-2 production correlates with this phenotype $(14,70)$, and may occur as a consequence of memory $\mathrm{T}$ cell differentiation rather than a lack of costimulation in the synovial environment. The spontaneous expression of CD40-L mRNA by RA PB T cells could be explained either by extraarticular $\mathrm{T}$ cell activation events, or by the recirculation of activated SF $T$ cells to draining lymph nodes and then into the blood. Further phenotypic analysis of the PB T cell subsets would address this issue.

CD40-L has multiple proinflammatory effects through its interaction with CD40, expressed by B cells, monocytes, and dendritic cells. Thus, these studies suggest that CD40-L is 
likely to play a central role in the perpetuation of RA. Of importance, increased CD40-L expression has been demonstrated recently in patients with other autoimmune disease, including SLE and multiple sclerosis $(71,72)$. The benefits of CD40-L blockade have been demonstrated in several animal models of autoimmune disease, including collagen-induced arthritis (73). Particularly promising was the induction of longterm graft acceptance after blockade of both CD40-L and CD80/CD86 in a cardiac allograft model (74). Taken together, these animal studies and our evidence of functional CD40-L expression in RA suggest that therapeutic blockade of CD40-L may prove to be highly effective. Moreover, the effectiveness of combinations of mAbs in an animal model renews optimism that remission-inducing therapy for RA might be achievable.

\section{Acknowledgments}

Dr. Thomas and Dr. MacDonald are supported by the Arthritis Foundation of Queensland. This work was supported by the Arthritis Foundation of Australia and by National Institutes of Health grant AR-37169.

\section{References}

1. Fox, R.I., S. Fong, N. Sabharwal, S.A. Carstens, P.C. Kung, and J.H. Vaughan. 1982. Synovial fluid lymphocytes differ from peripheral blood lymphocytes in patients with rheumatoid arthritis. J. Immunol. 128:351-354.

2. Pitzalis, C., G. Kingsley, J.S. Lanchbury, J. Murphy, and G. Panayi. 1987. Expression of HLA-DR, DQ and DP antigens and interleukin-2 receptor on synovial fluid T lymphocyte subsets in rheumatoid arthritis: evidence for "frustrated" activation. J. Rheumatol. 14:662-666.

3. Pitzalis, C., G. Kingsley, D. Haskard, and G. Panayi. 1988. The preferential accumulation of helper-inducer T lymphocytes in inflammatory lesions: evidence for regulation by selective endothelial and homotypic adhesion. Eur. J. Immunol. 18:1397-1404.

4. Cush, J.J., and P.E. Lipsky. 1988. Phenotypic analysis of synovial tissue and peripheral blood lymphocytes isolated from patients with rheumatoid arthritis. Arthritis Rheum. 31:1230-1238.

5. Potocnik, A.J., R. Kinne, H. Menninger, J. Zacher, F. Emmrich, and R.A. Kroczek. 1990. Expression of activation antigens on T cells in rheumatoid arthritis patients. Scand. J. Immunol. 31:213-224.

6. Wernick, R.M., P.E. Lipsky, E. Marban-Arcos, J.J. Maliakkal, D. Edelbaum, and M. Ziff. 1985. IgG and IgM rheumatoid factor synthesis in rheumatoid synovial membrane cell cultures. Arthritis Rheum. 28:742-752

7. Ridley, M.G., G. Kingsley, C. Pitzalis, and G.S. Panayi. 1990. Monocyte activation in rheumatoid arthritis: evidence for in situ activation and differentiation in joints. Br. J. Rheumatol. 29:84-88.

8. Hahn, G., B. Stuhlmuller, N. Hain, J.R. Kalden, K. Pfizenmaier, and G.R. Burmester. 1993. Modulation of monocyte activation in patients with rheumatoid arthritis by leukopheresis therapy. J. Clin. Invest. 91:862-870.

9. Koch, A.E., S.L. Kunkel, L.A. Harlow, B. Johnson, H.L. Evanoff, G.K. Haines, M.D. Burdick, R.M. Pope, and R.M. Strieter. 1992. Enhanced production of monocyte chemoattractant protein-1 in rheumatoid arthritis. J. Clin. Invest. 90:772-779.

10. Thomas, R., L.S. Davis, and P.E. Lipsky. 1994. Rheumatoid synovium is enriched in mature antigen-presenting dendritic cells. J. Immunol. 152:26132623.

11. Thomas, R., and C. Quinn. 1996. Functional differentiation of dendritic cells in rheumatoid arthritis: role of CD86 in the synovium. J. Immunol. 156: 3074-3086.

12. Emery, P., K.C. Gentry, I.R. Mackay, K. Muirden, and M. Rowley. 1987. Deficiency of the suppressor inducer subset of T lymphocytes in rheumatoid arthritis. Arthritis Rheum. 30:849-856.

13. Morimoto, C., P.L. Romain, D.A. Fox, P. Anderson, M. Dimaggio, H. Levin, and S.F. Schlossman. 1988. Abnormalities in CD4+ T-lymphocyte subsets in inflammatory rheumatic diseases. Am. J. Med. 84:817-825.

14. Thomas, R., M. McIlraith, L.S. Davis, and P.E. Lipsky. 1992. Rheumatoid synovium is enriched in CD45RBdim mature memory $\mathrm{T}$ cells that are potent helpers for B cell differentiation. Arthritis Rheum. 35:1455-1465.

15. Mason, D.W., and F. Powrie. 1990. Memory CD4+ T cells in man form two distinct subpopulations, defined by their expression of isoforms of the leucocyte common antigen, CD45. Immunology. 70:427-433.

16. Horgan, K.J., Y. Tanaka, G.E. Luce, G.A. van Seventer, T.B. Nutman, and S. Shaw. 1994. CD45RB expression defines two interconvertible subsets of human CD4+ T cells with memory function. Eur. J. Immunol. 24:1240-1243.

17. Firestein, G.S., and N.J. Zvaifler. 1990. How important are T cells in chronic rheumatoid synovitis? Arthritis Rheum. 33:768-773.

18. Kitas, G.D., M. Salmon, and P.A. Bacon. 1988. The T cell system in rheumatoid arthritis: activated or defective? Scand. J. Rheumatol. Suppl. 76: 161-173.

19. Dolhain, R.J., N.T. ter Haar, S. Hoefakker, P.P. Tak, M. de Ley, E. Claassen, F.C. Breedveld, and A.M. Miltenburg. 1996. Increased expression of interferon (IFN)-gamma together with IFN-gamma receptor in the rheumatoid synovial membrane compared with synovium of patients with osteoarthritis. $\mathrm{Br}$. J. Rheumatol. 35:24-32.

20. Aaron, S., and V. Paetkau. 1991. Synovial cell secretion of IL-2 in vitro, a limiting dilution analysis. Clin. Exp. Rheumatol. 9:113-118.

21. Chen, E., E.C. Keystone, and E.N. Fish. 1993. Restricted cytokine expression in rheumatoid arthritis. Arthritis Rheum. 36:901-910.

22. Burmester, G.R., and F. Emmrich. 1993. Anti-CD4 therapy in rheumatoid arthritis. Clin. Exp. Rheumatol. 11:S139-S145.

23. Panayi, G.S., and P. Tugwell. 1994. The use of cyclosporin A in rheumatoid arthritis: conclusions of an international review. Br. J. Rheumatol. 33:967969

24. Tak, P.P., P.A. van der Lubbe, A. Cauli, M.R. Daha, T.J. Smeets, P.M Kluin, A.E. Meinders, G. Yanni, G.S. Panayi, and F.C. Breedveld. 1995. Reduction of synovial inflammation after anti-CD4 monoclonal antibody treatment in early rheumatoid arthritis. Arthritis Rheum. 38:1457-1465.

25. Moreland, L.W., P.W. Pratt, M.D. Mayes, A. Postlethwaite, M.H. Weisman, T. Schnitzer, R. Lightfoot, L. Calabrese, D.J. Zelinger, J.N. Woody, et al. 1995. Double-blind, placebo-controlled multicenter trial using chimeric monoclonal anti-CD4 antibody, cM-T412, in rheumatoid arthritis patients receiving concomitant methotrexate. Arthritis Rheum. 38:1581-1588.

26. Elliott, M.J., R.N. Maini, M. Feldmann, A. Long-Fox, P. Charles, P. Katsikis, F.M. Brennan, J. Walker, H. Bijl, J. Ghrayeb, and J.N. Woody. 1993. Treatment of rheumatoid arthritis with chimeric monoclonal antibodies to tumor necrosis factor alpha. Arthritis Rheum. 12:1681-1690.

27. Rankin, E.C., E.H. Choy, D. Kassimos, G.H. Kingsley, A.M. Sopwith, D.A. Isenberg, and G.S. Panayi. 1995. The therapeutic effects of an engineered human anti-tumour necrosis factor alpha antibody (CDP571) in rheumatoid arthritis. Br. J. Rheumatol. 34:334-342.

28. Maini, R.N., M.J. Elliott, F.M. Brennan, R.O. Williams, C.Q. Chu, E. Paleolog, P.J. Charles, P.C. Taylor, and M. Feldmann. 1995. Monoclonal antiTNF alpha antibody as a probe of pathogenesis and therapy of rheumatoid disease. Immunol. Rev. 144:195-223.

29. Mulherin, D., O. Fitzgerald, and B. Bresnihan. 1996. Synovial tissue macrophage populations and articular damage in rheumatoid arthritis. Arthritis Rheum. 39:115-124.

30. Hollenbaugh, D., L.S. Grosmaire, C.D. Kullas, N.J. Chalupny, S. BraeschAndersen, R.J. Noelle, I. Stamenkovic, J.A. Ledbetter, and A. Aruffo. 1992 The human T cell antigen gp39, a member of the TNF gene family, is a ligand for the CD40 receptor: expression of a soluble form of gp39 with B cell co-stimulatory activity. EMBO (Eur. Mol. Biol. Organ.) J. 11:4313-4321.

31. Fanslow, W.C., S. Srinivasan, R. Paxton, M.G. Gibson, M.K. Spriggs, and R.J. Armitage. 1994. Structural characteristics of CD40 ligand that determine biological function. Semin. Immunol. 6:267-278.

32. Peitsch, M.C., and J. Tschopp. 1995. Comparative molecular modelling of the Fas-ligand and other members of the TNF family. Mol. Immunol. 32:761772 .

33. Mazzei, G.J., M.D. Edgerton, C. Losberger, S. Lecoanet Henchoz, P. Graber, A. Durandy, J.F. Gauchat, A. Bernard, B. Allet, and J.Y. Bonnefoy. 1995. Recombinant soluble trimeric CD40 ligand is biologically active. J. Biol. Chem. 270:7025-7028

34. Spriggs, M.K., W.C. Fanslow, R.J. Armitage, and J. Belmont. 1993. The biology of the human ligand for CD40. J. Clin. Immunol. 13:373-380.

35. Caux, C., C. Massacrier, B. Vanbervliet, B. Dubois, C. Van-Kooten, I Durand, and J. Banchereau. 1994. Activation of human dendritic cells through CD40 cross-linking. J. Exp. Med. 180:1263-1272.

36. Alderson, M.R., R.J. Armitage, T.W. Tough, L. Strockbine, W.C Fanslow, and M.K. Spriggs. 1993. CD40 expression by human monocytes: regulation by cytokines and activation of monocytes by the ligand for CD40. J. Exp. Med. 178:669-674.

37. Kiener, P.A., P. Moran Davis, B.M. Rankin, A.F. Wahl, A. Aruffo, and D. Hollenbaugh. 1995. Stimulation of CD40 with purified soluble gp39 induces proinflammatory responses in human monocytes. J. Immunol. 155:4917-4925.

38. Ludewig, B., D. Graf, H.R. Gelderblom, Y. Becker, R.A. Kroczek, and G. Pauli. 1995. Spontaneous apoptosis of dendritic cells is efficiently inhibited by TRAP (CD40-ligand) and TNF-alpha, but strongly enhanced by interleukin10. Eur. J. Immunol. 25:1943-1950.

39. Arnett, F.C., S.M. Edworthy, D.A. Bloch, D.J. McShane, J.F. Fries, N.S. Cooper, L.A. Healey, S.R. Kaplan, M.H. Liang, H.S. Luthra, et al. 1988. The American Rheumatism Association 1987 revised criteria for the classification of rheumatoid arthritis. Arthritis Rheum. 31:315-324.

40. Goding, J.W. 1986. Monoclonal Antibodies: Principles and Practice. Academic Press Limited, London.

41. Thomas, R., and P.E. Lipsky. 1994. Human peripheral blood dendritic 
cell subsets: isolation and characterization of precursor and mature antigenpresenting cells. J. Immunol. 153:4016-4028.

42. Romani, N., S. Gruner, D. Brang, E. Kampgen, A. Lenz, B. Trockenbacher, G. Konwalinka, P.O. Fritsch, R.M. Steinman, and G. Schuler. 1994. Proliferating dendritic cell progenitors in human blood. J. Exp. Med. 180:83-93.

43. Thiele, D.L., M. Kurosaka, and P.E. Lipsky. 1983. Phenotype of the accessory cell necessary for mitogen-stimulated $\mathrm{T}$ and $\mathrm{B}$ cell responses in human peripheral blood: delineation by its sensitivity to the lysosomotropic agent, L-leucine methyl ester. J. Immunol. 131:2282-2290.

44. Thiele, D.L., and P.E. Lipsky. 1985. Modulation of human natural killer cell function by L-leucine methyl ester: monocyte-dependent depletion from human peripheral blood mononuclear cells. J. Immunol. 134:786-793.

45. Wysocki, L.J., and V.L. Sato. 1978. "Panning" for lymphocytes: a method for cell selection. Proc. Natl. Acad. Sci. USA. 75:2844-2848.

46. Shimadzu, M., H. Nunoi, H. Terasaki, R. Ninomiya, M. Iwata, S. Kanegasaka, and I. Matsuda. 1995. Structural organization of the gene for CD40 ligand: molecular analysis for diagnosis of X-linked hyper-IgM syndrome. Biochim. Biophys. Acta. 1260:67-72.

47. de Waal Malefyt, R., J. Abrams, B. Bennett, C.G. Figdor, and J.E. De Vries. 1991. Interleukin 10 (IL-10) inhibits cytokine synthesis by human monocytes: an autoregulatory role of IL-10 produced by monocytes. J. Exp. Med. 174:1209-1220.

48. Tohma, S., and P.E. Lipsky. 1991. Analysis of the mechanisms of T celldependent polyclonal activation of human B cells. Induction of human B cell responses by fixed activated T cells. J. Immunol. 146:2544-2552.

49. Laemmli, U.K. 1970. Cleavage of structural proteins during the assembly of the head of bacteriophage $\mathrm{T}_{4}$. Nature (Lond.). 227:680-685.

50. Casamayor Palleja, M., M. Khan, and I.C. Maclennan. 1995. A subset of CD4+ memory T cells contains preformed CD40 ligand that is rapidly but transiently expressed on their surface after activation through the $\mathrm{T}$ cell receptor complex. J. Exp. Med. 181:1293-1301.

51. Nishioka, Y., and P.E. Lipsky. 1994. The role of CD40-CD40 ligand interaction in human T cell-B cell collaboration. J. Immunol. 153:1027-1036.

52. Cella, M., D. Scheidegger, K. Palmer-Lehmann, P. Lane, A. Lanzavecchia, and G. Alber. 1996. Ligation of CD40 on dendritic cells triggers production of high levels of interleukin-12 and enhances T cell stimulatory capacity: T-T help via APC activation. J. Exp. Med. 184:747-752.

53. Yellin, M.J., K. Sippel, G. Inghirami, L.R. Covey, J.J. Lee, J. Sinning, E.A. Clark, L. Chess, and S. Lederman. 1994. CD40 molecules induce downmodulation and endocytosis of $\mathrm{T}$ cell surface $\mathrm{T}$ cell-B cell activating molecule/ CD40-L: potential role in regulating helper effector function. J. Immunol. 152: 598-608.

54. Graf, D., S. Muller, U. Korthauer, C. van Kooten, C. Weise, and R.A. Kroczek. 1995. A soluble form of TRAP (CD40 ligand) is rapidly released after T cell activation. Eur. J. Immunol. 25:1749-1754.

55. Calin, A., J. Elswood, and P.T. Klouda. 1989. Destructive arthritis, rheumatoid factor, and HLA-DR4. Susceptibility versus severity, a case-control study. Arthritis Rheum. 32:1221-1225.

56. van Zeben, D., J.M. Hazes, A.H. Zwinderman, J.P. Vandenbroucke, and F.C. Breedveld. 1993. Factors predicting outcome of rheumatoid arthritis: results of a follow-up study. J. Rheumatol. 20:1288-1296.

57. Matthews, N., P. Emery, D. Pilling, A. Akbar, and M. Salmon. 1993. Subpopulations of primed T helper cells in rheumatoid arthritis. Arthritis Rheum. 36:603-607.

58. Kohem, C.L., R.I. Brezinschek, H. Wisbey, C. Tortorella, P.E. Lipsky, and N. Oppenheimer Marks. 1996. Enrichment of differentiated CD45RBdim,CD27- memory T cells in the peripheral blood, synovial fluid, and syno- vial tissue of patients with rheumatoid arthritis. Arthritis Rheum. 39:844-854.

59. Castle, B.E., K. Kishimoto, C. Stearns, M.L. Brown, and M.R. Kehry. 1993. Regulation of expression of the ligand for CD40 on T helper lymphocytes. J. Immunol. 151:1777-1788.

60. Grammer, A.C., M.C. Bergman, Y. Miura, K. Fujita, L.S. Davis, and P.E. Lipsky. 1995. The CD40 ligand expressed by human B cells costimulates B cell responses. J. Immunol. 154:4996-5010.

61. Kroszek, R.A., D. Graf, D. Brugnoni, S. Gilliani, U. Korthauer, A.G Ugazio, G. Senger, H.W. Mages, A. Villa, and L.D. Notarangelo. 1994. Defective expression of CD40 ligand on T cells causes X-linked immunodeficiency with hyper IgM (HIGMI). Immunol. Rev. 138:39-59.

62. Patel, H.R., A. Oshiba, J.D. Jeppson, and E.W. Gelfand. 1996. Differential expression of CD40 ligand on T cell subsets. Implications for different roles of CD45RA+ and CD45RO+ cells in IgE production. J. Immunol. 156:17811787.

63. Hollenbaugh, D., L.H. Wu, H.D. Ochs, S. Nonoyama, L.S. Grosmaire J.A. Ledbetter, R.J. Noelle, H. Hill, and A. Aruffo. 1994. The random inactivation of the $\mathrm{X}$ chromosome carrying the defective gene responsible for X-linked hyper IgM syndrome (X-HIM) in female carriers of HIGM1. J. Clin. Invest. 94: 616-622.

64. Mach, F., U. Schönbeck, G.K. Sukhova, T. Bourcier, J.Y. Bonnefoy, J.S. Pober, and P. Libby. 1997. Functional CD40 ligand is expressed on human vascular endothelial cells, smooth muscle cells, and macrophages: implications for CD40-CD40 ligand signaling in atherosclerosis. Proc. Natl. Acad. Sci. USA. 94: 1931-1936.

65. van Kooten, C., C. Gaillard, J.P. Galizzi, P. Hermann, F. Fossiez, J. Banchereau, and D. Blanchard. 1994. B cells regulate expression of CD40 ligand on activated $\mathrm{T}$ cells by lowering the mRNA level and through the release of soluble CD40. Eur. J. Immunol. 24:787-792.

66. Durie, F.H., T.M. Foy, S.R. Masters, J.D. Laman, and R.J. Noelle. 1994 The role of CD40 in the regulation of humoral and cell-mediated immunity. Immunol. Today. 15:406-411.

67. Hoxie, J.A., D.M. Matthews, K.J. Callahan, D.L. Cassel, and R.A. Cooper. 1986. Transient modulation and internalization of T4 antigen induced by phorbol esters. J. Immunol. 137:1194-1201.

68. Howell, M., J. Smith, and M. Cawley. 1992. The rheumatoid synovium: a model for T cell anergy? Immunol. Today. 13:191.

69. Schwartz, R.H. 1996. Models of T cell anergy: is there a common molecular mechanism? J. Exp. Med. 184:1-8.

70. Tortorella, C., H. Schulze-Koops, R. Thomas, J.B. Splawski, L.S. Davis, L.J. Picker, and P.E. Lipsky. 1995. Expression of CD45RB and CD27 identifies subsets of CD4+ memory T cells with different capacities to induce B cell differentiation. J. Immunol. 155:149-162.

71. Desai Mehta, A., L. Lu, R. Ramsey Goldman, and S.K. Datta. 1996. Hyperexpression of CD40 ligand by B and T cells in human lupus and its role in pathogenic autoantibody production. J. Clin. Invest. 97:2063-2073.

72. Gerritse, K., J.D. Laman, R.J. Noelle, A. Aruffo, J.A. Ledbetter, W.J. Boersma, and E. Claassen. 1996. CD40-CD40 ligand interactions in experimental allergic encephalomyelitis and multiple sclerosis. Proc. Natl. Acad. Sci. USA. 93:2499-2504.

73. Durie, F.H., R.A. Fava, T.M. Foy, A. Aruffo, J.A. Ledbetter, and R.J. Noelle. 1993. Prevention of collagen-induced arthritis with an antibody to gp39, the ligand for CD40. Science (Wash. DC). 261:1328-1330.

74. Larsen, C.P., E.T. Elwood, D.Z. Alexander, S.C. Ritchie, R. Hendrix, C. Tucker Burden, H.R. Cho, A. Aruffo, D. Hollenbaugh, P.S. Linsley, et al. 1996. Long-term acceptance of skin and cardiac allografts after blocking CD40 and CD28 pathways. Nature (Lond.). 381:434-438. 